\title{
FEATURES OF APPLICATION OF THE FORECASTING SIMULATION MODEL IN THE PLANNING PROCESS IN THE ENTERPRISE
}

\author{
OLZHABAYEVA Dinara ${ }^{1}$, PETROVSKAYA Maria Vladimirovna ${ }^{2}$ \\ ${ }^{1}$ RUDN University (RUSSIAN FEDERATION) \\ ${ }^{2}$ RUDN University (RUSSIAN FEDERATION) \\ E-mails: dinara.olzhabayeva@yandex.kz,petrovskaya-mv@rudn.ru
}

\begin{abstract}
This article discusses the features of using a multi-level simulation model of financial and economic forecasting when planning the activities of an enterprise operating in the railway industry, in particular in the segment of national and international freight transportation. The authors set a goal to show how, through the use of a multi-level simulation model of forecasting, it is possible to significantly increase the reliability of organizational and managerial decisions and ensure a more efficient allocation of resources and reduction of financial risks.

The model constructed by the authors can be used to optimize costs, improve the quality of settlements with debtors and creditors, plan the cost and other indicators of financial and economic activity, the ability to build various forecast scenarios allows you to choose the most acceptable option for the company, taking into account the impact of key factors on the financial result and the level of financial risk.
\end{abstract}

Keywords: Financial And Economic planning, forecasting, multi-level simulation models, the railway industry.

JEL: P34

DOI: $10.5937 /$ intrev2102025O

UDC: $658.14: 656.025 .4(47)$

COBISS.SR-ID 43524617 


\section{INTRODUCTION}

The COVID-19 pandemic has had a significant impact on the economies of all countries in the world and, as a result, on the activities of enterprises in all industries. If earlier the heads of enterprises showed stronger interest in long-term strategic plans, explaining this by the desire for development and stability, then with the onset of the pandemic it became clear to everyone that there is nothing stable in the modern world. Thereby there are no guarantees that if the enterprise fulfills all points of the strategic plan, it will receive the same profit and come to the same financial results. This situation has shown the importance, significance and necessity of developing short-term operational plans and forecasts, considering the maximum number of factors and risks affecting the activities of the enterprise.

Talking about the railway industry, the consequences of the pandemic had a rather negative impact on the passenger transportation segment. However, the imposed restrictive measures did not affect the volume of freight traffic. The biggest adjustment made by the pandemic to the freight transportation system is concern for the health of people, in particular, minimizing contact between suppliers, employees of the enterprise and customers. A significant impetus in the development was received by computer programs that allow employees to carry out their activities remotely. As for the process of freight transportation itself, the demand for the services of rail freight carriers has noticeably increased, and the volume of work has increased accordingly [1].

First of all, this is due to the fact that at the moment rail freight transport, compared to road freight transport, is the safest from the point of view of sanitary standards, since it does not require direct contact of customers with employees of enterprises, and employees of enterprises with suppliers and third parties. From a financial point of view, rail freight transportation is the least costly compared to air transportation, and the fastest in comparison with sea freight transportation [2].

In the context of an uncertain and unstable economic situation in the world, caused by the introduction of restrictive measures and the willingness of customers and managers of enterprises to protect themselves and their employees, the role of economic forecasting and operational planning increases. It can serve as the necessary airbag capable save the company from unforeseen costs, as well as calculate all the opportunities and risks that the company facing [3].

\section{METHODOLOGY}

In the present day conditions, depending on the tasks set, the amount of available information, various methods of planning and cost optimization are used. Well-known Russian and foreign scientists, such as A.N. Asaul, I.V. Drozdova, M.G. Kvitsinia, A.A. Petrov, V.V. Kovalev, L.S. Vasilyeva, A.D. Sheremet, K. Drury, A. Korreli and others, made a fairly large contribution to the development of methodological tools for cost management and their optimization [4] [5] [6] [7] [8] [9][10].

The issues of forecasting financial and economic activity, taking into account the impact of key factors, in different periods were dealt with by leading scientists from different countries W.J.Baumol, J.Tobin, A.H. Meltzer, R.D. Morris, M.H. Miller, V. Bocharov, V.E. Leontiev, R. Brailey, F. Allen, M. Stewart, O.P. Attanasio, L. Guizo, T. Jappelli [11] [12][13][14][15][16][17][18].

The methods and approaches considered by these authors make it possible to plan the entire financial and economic activities of the company, as well as individual projects implemented with the aim of modifying the business processes of the enterprise. In most cases, the application of these tools in practice is a rather laborious process that is not able to quickly adapt to changes in market conditions, which, as a result, leads to erroneous judgments of the company's management when making certain managerial decisions.

The purpose of this study is to ensure an improvement in the quality of financial forecasting through the use of a multilevel simulation model when drawing up and adjusting the operational plans of an enterprise operating in the field of freight rail transportation, by optimizing costs and improving the quality of resource use.

Based on this goal, the authors set the following tasks:

- to analyze the financial condition of the enterprise over the past three years, to analyze the structure of the cost of services rendered by the enterprise; 
- calculate the forecast indicators of the financial condition of the enterprise, determine the lower and upper threshold of the forecast indicators;

- determine hidden reserves and the most significant cost items;

- to develop a number of proposals for cost optimization, taking into account external and internal factors.

The use of simulation forecasting models is widely used in the activities of large industrial and manufacturing enterprises [19]. However, the possibility of using these models in the activities of enterprises specializing in the services (in our case, services for the transportation of goods, the provision of wagons and locomotive traction) is a rather controversial issue, which we will try to deal with.

In the course of the research, general scientific methods of cognition were used - system analysis, methods of factor and comparative analysis, modeling, as well as specific tools for the formation of balanced indicator systems, aggregated indicators. The use of modern mathematical, statistical and other modern methods made it possible to ensure a high level of reliability of the conducted research.

\section{RESULTS}

As the analyzed enterprise, we have chosen the joint-stock company "KTZ-Freight transportation". This enterprise is a subsidiary of the Joint Stock Company National Company "Kazakhstan Temir Zholy" (hereinafter referred to as JSC NC "KTZ") and carries out activities to provide: 1) services for cargo transportation; 2) the management services for the transportation process; 3) services of locomotive traction in passenger traffic; 4) services of locomotive traction in freight traffic and other services [20].

In the process of applying the above models, the initial data obtained from: main financial documents: the statement of financial position of the enterprise, the statement of profit and loss and other comprehensive income, the statement of changes in equity and notes to the financial statements for the last several periods, as well as information about development of the enterprise and its management strategy.

It is worth noting the fact that during calculations, we will base the applied model on the concept that our enterprise, unlike industrial enterprises due to the specifics of its activities, will never be able to work "for a warehouse". As a result, the volume of production will always be is equal to and depends on the volume of sales, or rather on the volume of demand and the availability of resources to satisfy it.

Level I. As the initial data, we will use the statement of profit and loss and other comprehensive income of KTZ-Freight transportation JSC for the period from 2017 to 2019 (Table 1).

\section{Table 1. Initial data for JSC "KTZ-Freight transportation" (in thousand tenge)}

\begin{tabular}{|l|l|l|l|}
\hline The name of indicators & 2017 & 2018 & 2019 \\
\hline Revenue (sales volume) & 776377108 & 862621009 & 934857406 \\
\hline Prime cost & -698928524 & -764403 & \\
\hline Gross profit & 77448584 & 967 & -856066243 \\
\hline General and administrative expenses & -14924519 & 98217042 & 78791163 \\
\hline Non-operating income/expenses: & -22693050 & -16572949 & -17557094 \\
\hline financial income & 375662 & -48954059 & -17513573 \\
\hline financial expenses & -22094890 & 1163491 & $1,294,849$ \\
\hline foreign exchange gain/loss & -4385768 & -24082348 & -20061793 \\
\hline other net income & 3411946 & -28686609 & -1779909 \\
\hline Profit before tax & $39,831,015$ & 2651407 & $3,033,280$ \\
\hline Corporate income tax expense / savings: & -10224351 & 32690034 & 43720496 \\
\hline current income tax expense & -7966203 & -9161533 & -11208792 \\
\hline prior year corporation tax adjustment & - & -6538007 & -8744099 \\
\hline non-deductible expenses when calculating CIT & -2258148 & -541564 & - \\
\hline Annual profit & 29606664 & -2081962 & -2464693 \\
\hline Accumulated other comprehensive income/loss & -1726159 & 23528501 & 32511704 \\
\hline Total annual comprehensive income & 27880505 & -761241 & -1127783 \\
\hline $\begin{array}{l}\text { Source: compiled by the authors of the article based on data from the consolidated financial statements of KTZ- } \\
\text { Freight Transportation JSC for the period from 2017 to 2019 }\end{array}$ & & \\
\hline
\end{tabular}


To analyze the financial condition of the enterprise dynamics, the cumulative average annual growth rate (CAGR) was calculated using the following formula:

$\operatorname{CAGR}\left(t_{0}, t_{n}\right)=\frac{V t_{n}}{V t_{0}} \frac{1}{t_{n}-t_{0}}-1$

$\mathbf{V t}_{\mathbf{0}^{-}}$the initial value of the analyzed indicator;

$\boldsymbol{V} \boldsymbol{t}_{\boldsymbol{n}^{-}}$the final value of the analyzed indicator;

$t_{n}, t_{0}$ - the number of years.

Analyzing the data presented in the financial statements of the enterprise, you can notice a certain trend in the growth of indicators: revenue by $8-11 \%$, general and administrative expenses by $6-11 \%$, financial income by $11-210 \%$.

There is also both positive and negative dynamics of the following indicators: financial expenses changed from $-17 \%$ to $+9 \%$, the forecasted level of loss / profit from exchange rate differences (according to financial statements) changed from $-10 \%$ to $+10 \%$, other income changed from $-22 \%$ to $+14 \%$, nondeductible expenses when calculating corporate income tax changed from $-8 \%$ to $+18 \%$, other comprehensive income / loss changed from $-56 \%$ to $+48 \%$.

Corporate income tax rate was $20 \%$ in the period from 2017 to 2019.

Using the data obtained, as well as calculating the share of the cost in thousand tenge, revenue for each period and determining its lower and upper threshold, we will be able to calculate the forecast values of financial indicators contained in the statement of profit and loss and other comprehensive income (Table 2).

In this case, the simulation model will consider two conditions: 1) the smallest values of the share of prime cost in revenue and growth rates of other indicators of the enterprise (lower threshold); 2) the highest values of the share of prime cost in revenue and growth rates of other indicators of the enterprise (upper threshold).

Table 2. Forecasted values of financial indicators of JSC "KTZ-Freight transportation" (in thousand tenge)

\begin{tabular}{|c|c|c|}
\hline \\
\hline The name of indicators & 2020 (lower threshold) & 2020 (upper threshold) \\
\hline Revenue (sales volume) & 1,013142922 & 1,038706101 \\
\hline Prime cost & -897787627 & -951162417 \\
\hline Gross profit & 115355295 & 87543684 \\
\hline General and administrative expenses & -18599680 & -19496295 \\
\hline Non-operating income/expenses: & -14516204 & -16343745 \\
\hline financial income & $1,441,037$ & 4010374 \\
\hline financial expenses & -16712471 & -21866372 \\
\hline foreign exchange gain/loss & -1601918 & -1957900 \\
\hline other net income & 2357147 & 3470153 \\
\hline Profit before tax & $82,239,411$ & 51703644 \\
\hline Corporate income tax expense / savings: & -18720274 & -13258511 \\
\hline current income tax expense & -16447882 & -10340729 \\
\hline $\begin{array}{l}\text { prior year corporation tax adjustment } \\
\text { non-deductible expenses when calculating CIT }\end{array}$ & $\begin{array}{l}- \\
-2272392\end{array}$ & $\begin{array}{l}- \\
-2917782\end{array}$ \\
\hline Annual profit & 63519137 & 38445134 \\
\hline Accumulated other comprehensive income/loss & -497355 & -1670817 \\
\hline Total annual comprehensive income & 63,021781 & 36774317 \\
\hline
\end{tabular}

Analyzing the data obtained, it should be noted that there is a significant difference between the projected net profit at the lower threshold of indicators $(63,021,781$ thousand tenge) and between the projected net profit at the upper threshold of indicators (36,774,317 thousand tenge). The difference is $26,247,465$ thousand tenge.

Level II. As the initial data, we used data on the cost of services provided by JSC KTZ-Freight transportation, presented in attachment to the consolidated financial statements for 2017-2019 (Table 3). 
Table 3. Information on the cost of services provided by the enterprise JSC "KTZ-Freight transportation" in the period from 2017 to 2019 (in thousand tenge)

\begin{tabular}{|l|l|l|l|}
\hline The name of indicators & 2017 & 2018 & 2019 \\
\hline Prime cost & $698,928,524$ & 764403967 & 856066243 \\
\hline Services for access to main railway networks & 322842201 & 330479206 & 401342933 \\
\hline Personnel costs (wages and social security contributions) & 102784342 & 117106397 & 124585964 \\
\hline Maintenance of locomotives and other services & 92799118 & 111985912 & 115233357 \\
\hline Fuel and lubricants & 81546502 & 105191095 & 110165593 \\
\hline Electricity & 36614855 & 38354636 & 39220875 \\
\hline Depreciation and amortization & $16,716,947$ & 17126610 & 18255370 \\
\hline Security and cargo escort services & 11414950 & $13,271,807$ & 12521245 \\
\hline Service of traction power supply & 10908803 & $9,070,177$ & 9427992 \\
\hline Materials and supplies & 7795691 & 8800526 & 6887303 \\
\hline Employee benefits & 2814571 & $3,903,584$ & $6,025,926$ \\
\hline Wagon hire charge & $1,571,957$ & $1,589,182$ & $1,315,902$ \\
\hline Other expenses & 11118587 & 7524835 & 11083783 \\
\hline $\begin{array}{l}\text { Source: compiled by the authors of the article based on data from the consolidated financial statements of KTZ- } \\
\text { Freight Transportation JSC for the period from 2017 to 2019 }\end{array}$ & & \\
\hline
\end{tabular}

In order to assess the degree of influence of indicators on the cost price and to more clearly examine their dynamics, it is necessary to conduct a vertical analysis of the available data (Table 4).

Table 4:Vertical analysis of indicators that form the cost of services provided by JSC "KTZ - Freight Transportation" (in percent (\%))

\begin{tabular}{|l|l|l|l|}
\hline The name of indicators & 2017 & 2018 & 2019 \\
\hline Prime cost & $100 \%$ & $100 \%$ & $100 \%$ \\
\hline Services for access to main railway networks & $46.19 \%$ & $43.23 \%$ & $46.88 \%$ \\
\hline Personnel costs (wages and social security contributions) & $14.71 \%$ & $15.32 \%$ & $14.55 \%$ \\
\hline Maintenance of locomotives and other services & $13.28 \%$ & $14.65 \%$ & $13.46 \%$ \\
\hline Fuel and lubricants & $11.67 \%$ & $13.76 \%$ & $12.87 \%$ \\
\hline Electricity & $5.24 \%$ & $5.02 \%$ & $4.58 \%$ \\
\hline Depreciation and amortization & $2.39 \%$ & $2.24 \%$ & $2.13 \%$ \\
\hline Security and cargo escort services & $1.63 \%$ & $1.74 \%$ & $1.46 \%$ \\
\hline Service of traction power supply & $1.56 \%$ & $1.19 \%$ & $1.10 \%$ \\
\hline Materials and supplies & $1.12 \%$ & $1.15 \%$ & $0.80 \%$ \\
\hline Employee benefits & $0.40 \%$ & $0.51 \%$ & $0.70 \%$ \\
\hline Wagon hire charge & $0.22 \%$ & $0.21 \%$ & $0.15 \%$ \\
\hline Other expenses & $1.59 \%$ & $0.98 \%$ & $1.29 \%$ \\
\hline $\begin{array}{l}\text { Source: compiled by the authors of the article based on data from the consolidated financial statements of KTZ- } \\
\text { Freight Transportation JSC for the period from 2017 to 2019 }\end{array}$ & & \\
\hline
\end{tabular}

\section{CONCLUSIONS AND RECOMMENDATIONS}

Analyzing the presented data, it could be mentioned, that the most of the company's expenses in the formation of the cost are related to services for access to main railway networks. This service is provided to the company by the parent company JSC NC KTZ, the cost of the service is fixed and regulated by the Committee for the Regulation of Natural Monopolies Republic of Kazakhstan. At the moment, JSC NC "KTZ" is working on the settlement of this issue and amending the tariff policy, as well as in a number of legislative acts regulating the operation of railway transport in the Republic of Kazakhstan [21].

The second in terms of costs is the indicator of personnel costs (wages and social security contributions), in order to optimize the data, the enterprise is recommended to:

- develop the monitoring and evaluating plan to determine the effectiveness of employees;

- consider the possibility of reducing jobs, expanding the area of responsibility of employees with a proportional increase in salary; 
- instruct and train the management staff of departments and divisions, aimed at improving the

qualifications of employees in specific areas related to their core activities.

The third in terms of volume is the cost of "maintenance of locomotives and other services". To improve this indicator, the enterprise is recommended to:

- regularly identify the most common problems associated with the failure of locomotives and other equipment;

- develop a plan of necessary measures to solve the identified problems, monitor the implementation of the approved plan;

- in order to optimize the process of storing and supplying the necessary materials (spare parts and production inventory), consider the possibility of introducing the "Just in time" system in the divisions dealing with the repair and maintenance of locomotives and other equipment.

The next indicator in terms of the costs volume is the cost of fuels and lubricants. Optimization of this indicator is possible only when switching to a more energy efficient type of fuel, since KTZ-Freight Transportation JSC, organizing tenders, thus acquires fuel and lubricants at the lowest price offered on the market. According to the latest data, the news portal SK News, JSC NC "KTZ" is already taking measures to deal with this issue. In particular, the management of NC KTZ JSC signed an agreement with KazTransGas JSC on cooperation in the use of liquefied natural gas (hereinafter - LNG) on diesel locomotives with gas diesel engines [22]. Therefore, the main task of JSC "KTZ - Freight Transportation" should be to resolve issues related to the possibility of using this type of fuel.

Electricity costs are also one of the most significant components of the cost of services provided by KTZ-Freight Transportation JSC. The way to solve this problem directly depends on its source, that is, the type of activity, or the division of the enterprise that consumes that electricity itself. If the source is locomotives (in particular electric locomotives), then the enterprise should consider the possibility of a phased transition from electric locomotives to diesel locomotives using liquefied natural gas as fuel. If the source is a division of the enterprise (for repair and maintenance of locomotives), then it is necessary to consider the possibility of using less energy-intensive equipment in the activities of this division.

Optimization of other cost items is also quite possible, but first of all, the enterprise needs to solve the largest issues related to costs described above. It is also necessary not to forget to regularly analyze the performance of the enterprise in dynamics, since the optimization of one cost item can significantly affect other indicators. For example, the issue related to the costs associated with depreciation and amortization may lose its relevance after solving the issue related to the maintenance of locomotives, but the solution to the issue of increasing the efficiency of the staff and the volume of wages may affect the costs spent on employee benefits etc.

To calculate the forecast values of cost indicators as the volume of cost in the forecast period, we will use the values of the upper and lower cost thresholds calculated at level I (Table 2), as well as indicators of vertical analysis of the structure of the cost of services for 2019, calculated at level II (Table 4). As a result, we will receive the predicted value of the cost indicators included in the cost of services provided by KTZ - Freight Transportation JSC (Table 5).

Table 5: Forecasted value of cost indicators included in the cost of services provided by KTZ - Freight Transportation JSC for 2020

\begin{tabular}{|l|l|l|}
\hline The name of indicators & $2020(\mathrm{NP})$ & $2020(\mathrm{VP})$ \\
\hline Prime cost & 897787627 & 951162417 \\
\hline Services for access to main railway networks & 420902848 & 445926139 \\
\hline Personnel costs (wages and social security contributions) & 130657806 & 138425604 \\
\hline Maintenance of locomotives and other services & 120849389 & $128,034,062$ \\
\hline Fuel and lubricants & 115534641 & 122403345 \\
\hline Electricity & $41,132,350$ & 43577728 \\
\hline Depreciation and amortization & 19145067 & 20283269 \\
\hline Security and cargo escort services & 13131482 & 13912168 \\
\hline Service of traction power supply & 9887476 & 10475301 \\
\hline Materials and supplies & $7,222,964$ & 7652379 \\
\hline Employee benefits & 6319607 & 6695316 \\
\hline Wagon hire charge & $1,380,034$ & $1,462,079$ \\
\hline Other expenses & 11623964 & 12315026 \\
\hline Source: Authors & & \\
\hline
\end{tabular}


These indicators can serve as indicators reflecting the maximum allowable or minimum possible level of costs (in the absence of any measures to optimize them) for certain resources included in the cost of the services provided.

In addition, the company's management can use this model to calculate the degree of influence of the introduced or planned for implementation changes related to certain financial indicators, for this it is necessary to make adjustments to the values of the indicators to the extent that changes are planned or have already occurred in this period.

The multi-level simulation model used in this study makes it possible to:

- determine the relationship between the financial performance of the enterprise,

- assess the influence degree of indicators on each other and on the financial result of the enterprise as a whole;

- by making adjustments, calculate the various scenarios that are possible in the activities of the enterprise, and assess the degree of influence of the adjustments made on the financial result of the enterprise;

- apply the predicted values calculated using the model when developing operational and strategic plans of the enterprise.

The main limitation for the application of this model is the complexity of its building process. In particular, the definition of links and dependencies between indicators. It is important to consider every detail. The more reliable relationships are established in the process of building a model, the more accurate the result will be.

In this work, there was considered only one direction of application of the multi-level simulation model. In fact, this model can be applied not only in the process of analyzing and planning prime costs, but also in planning general and administrative costs, schedules for accounts payable and receivable and other indicators. In addition, subject to the construction of all relationships and dependencies between the indicators, this model enables the preparation of forecast balance of the enterprise.

\section{REFERENCES}

[1] Abdullaev D. (2020) "How the pandemic affected container transportation in Kazakhstan and the world..." // Kursiv Newspaper, issue №33 from 07/05/2020. Retrieved from https://kursiv.kz/news/kompanii/2020-07/kak-pandemiya-povliyala-na-konteynernye-perevozki-vkazakhstane-i-mire

[2] Pavlov V. (2020) "A pandemic is a common problem (conversation with the General Director of Russian Railways, Sergei Pavlov)" // Newspaper Gudok, issue No. 60 from 06/04/2020. Retrieved from https://gudok.ru/newspaper/?ID=1499734\& archive=2020.04.06

[3] Yohn, Teri Lombardi (2020). Research on the use of financial statement information for forecasting profitability. ACCOUNTING AND FINANCE, Volume: 6, Issue: 3 , Pages: 3163-3181, Published: SEP 2020. DOI: 10.1111/acfi.12394

[4] Asaul A. N., Drozdova I. V., Kvitsinia M. G., Petrov A. A. (2021) Cost management and controlling: a textbook for universities / Moscow: Yurayt Publishing House, 263 p.

[5] Kovalev V. V., Kovalev V. V. (2014) Corporate finance and accounting [Text]: concepts, algorithms, indicators: textbook. - 2nd ed., reprint. And additional - Moscow: Prospekt, 873 p.

[6] Vasilyeva L. S., Petrovskaya M. V. (2006) Financial analysis: textbook. For university students studying in econ. Specialties /Moscow: Knorus, 544 p.

[7] Sheremet A.D. (2020) Analysis and diagnostics of financial and economic activity of the enterprise: textbook / A.D. Sheremet. - 2nd ed., add. - Moscow: INFRA-M, 374 p.

[8] Drury K. (2017) Management accounting for business solutions: Textbook / Trans. from English-M.: UNITY-DANA, $655 \mathrm{p}$.

[9] Angelo Corelli, (2018) Analytical Corporate Finance//Springer Texts in Business and Economics, 2nd ed., $501 \mathrm{p}$. 
[10] Schuster P., Heinemann M., Cleary P. (2021), Management Accounting//Springer Texts in Business and Economics, $314 \mathrm{p}$.

[11] Baumol W.J. (1952) The transactions demand for cash: an inventory theoretic approach. The Quarterly Journal of Economics, Vol. 66, No. 4 (Nov., 1952), pp. 545-556

[12] Tobin J. (1956) The interest-elasticity of transactions demand for cash, The Review of Economics and Statistics, August (1956) 241-247.

[13] Meltzer A. H. (1963) The demand for money: a cross section study of business firms, Quarterly journal of economics, Aug. 1963, pp. 405421.

[14] Morris R. D. (1971) Transactions demand for cash, Quarterly journal of economics, Aug. 1971, pp. 546547.

[15] Miller M.H., Orr D. (1966) A Model of the Demand for Money by Firms. The Quarterly Journal of Economics, Volume 80, Issue 3, August 1966, Pages 413-435

[16] Bocharov V. V., Leontiev V. E. (2004) Corporate finance. St. Petersburg: Peter, 2004. - 592 p.

[17] Brayley Richard, Allen Franklin, Myers Stewart (2019) Principles of corporate finance. Basic course: translated by V. L. Akulov, edited by A.V. Bukhvalov, Moscow: Williams, 576 p.

[18] Attanasio, O.P., Guiso L. And Jappelli T. (2002) The Demand for Money, Financial Innovation, and the Welfare Cost of Inflation: An Analysis with Households' Data. Journal of Political Economy. Vol. 110, Number 2, 2002, pp. 317-351.

[19] Marr Bernard (2016). Key business analytics: the 60+ business analysis tools every manager needs to know. Harlow, England: Pearson Education Limited

[20] Charter of JSC "KTZ-Freight transportation" approved by the decision of the board of directors of OJSC NC "KTZ" Protocol No. 4 from 03/19/2020 // Retrieved November 9, 2020 from official website of JSC "KTZ-Freight transportation" : https://ktzh-gp.kz/ru/about/charter/

[21] Mamyshev J. (2020) "KTZ receives less income due to tariff policy" // Newspaper Kursiv, issue No. 27 of 04/22/2020. Retrieved from https://kursiv.kz/news/kompanii/2020-04/ktzh-nedopoluchaetbolshuyu-chast-dokhodov-iz-za-tarifnoy-politiki

[22] SK News (2020). Environmentally friendly fuel for KTZ locomotives. Retrieved November 15, 2020 from: https://sknews.kz/news/view/ekologicheski-chistoe-toplivo-dlya-lokomotivov-ktgh

\section{Article history:}

Received 12 April 2021

Accepted 15 July 2021 